\title{
A Research on the Cognitive Structure of Middle School Students Regarding Concepts of Nature and Environment
}

\author{
Mustafa Kahyaoğlu, Muzaffer Çatak \\ Siirt University, Siirt, Turkey
}

\begin{abstract}
The purpose of this study is to reveal the cognitive structure of middle school students regarding concepts of nature and environment. In this study, phenomenological pattern, a form of qualitative research was used. The study group comprised 137 middle school students, who were studying in schools located in Siirt City in Turkey that are part of the provincial directorate of national education during the Fall Semester of the 2015-2016 academic year. In this study, the Word Association Test was used as the data collection tool. In this Word Association Test, middle school students were given two key concepts - nature and environment. They were asked to write down words that came to mind and that they associated with these concepts, and to use them to make a sentence in a given time. In the analysis of the data obtained, a frequency table was used, composed of the responses that related to the key concepts of nature and environment. Additionally, in accordance with data received, a concept network was formed to establish the students' cognitive structure related to concepts of nature and environment. According to the study findings, middle school students were not able to sufficiently relate to concepts of nature and environment in their cognitive structures and their minds showed some disconnections.
\end{abstract}

Keywords: nature, environment, cognitive structure, word association test, middle school students

\section{Introduction}

Concepts of nature and environment are classified in broad terms that are complex and difficult to comprehend, ranging from ecology to economy, geography to philosophy, sociology to psychology, and social to political sciences. According to the Turkish Language Association (TDK) (2016), a concept was a general term covering the common aspects of objects or events and combining them under a common name. Çepni (2008), on the other hand, defined concepts as the common name for objects and ideas that shared similar characteristics and other phenomena that exhibited a specific behavior. Senemoğlu (2010) defined concepts as categories that classified events, objects, and states, while Kaptan (1999) suggested that concepts were abstract thinking units. In accordance with the constructivist theory, it is the relationship among concepts that form scientific principles. Starting from childhood, individuals begin to learn concepts that are the units of thoughts and the words that are used to name them, and explore their relationship by classifying them. In this way, people attribute meaning to what they already know, they organize these new meanings, and even produce new concepts and new information. The learning and restructuring process in the human mind continues uninterruptedly in all age groups (Ministry of National Education [MNE], 2005, p. 80). Constructivist theory 
also suggests that concepts are the essential building blocks of an individual's cognitive structure. According to this theory, it is not important to memorize information but to re-structure, interpret, and put into practice information, in the light of previous knowledge and experience. According to Kaptan (1999), concepts diminished the complexity related to the expression of problems related to the environment we lived in, facilitated communication among people and enabled the systematic grouping of information. For this reason, the teaching of concepts requires more than merely clarifying information. In order to ensure students learn accurate, meaningful, and interrelated concepts, it is important to take their cognitive structures into consideration. One of the aims of education is to ensure that students learn the concepts meaningfully by encouraging them to use these concepts in their daily life and in accordance with their own needs without memorizing them.

\section{Literature Review}

The TDK (2016) defined nature as an environment that had not undergone any major changes by human hands and remained in a natural state. On the other hand, the concept of environment is defined as the entirety of the living and non-living creatures that affect the milieu where the concept itself exists in lives, the all forces, and conditions. In other words, environment is defined as the totality of all physical, chemical, and biological factors that have an effect on the lives of all living things in a certain milieu (Yücel, 2006). According to this, environment encompasses all factors affecting the biological nature of living things. The concept of nature, on the other hand, is defined as an open system without definite borders, which shows a variety in terms of living and non-living things that affects and is affected by others. It is changing and changeable, possessing, renewable, and re-constructable characteristics formed without the influence of mankind, which can continue without the presence of human beings, has its own mechanisms and rules and that covers a variety of elements, facts, beings, relationships, interactions, and processes (Atasoy, 2005). While concepts of nature and environment are perceived to be similar, they are in fact concepts with different meanings, in terms of content and scope. At this stage, it is important to establish the cognitive structures of students related to these concepts. For example, we have a series of thoughts related to nature. When we hear the word "nature," we can think about both narrow concepts, such as "trees" and "forests," etc., and broad concepts, such as "the laws of nature," "the diversity of nature," etc.. Cognitive structure is defined as the mental schema and framework that organize and maintain the elements that constitute the knowledge during any learning process (Uçak \& Güzeldere, 2006). It has played an important role in determining and learning the relationship between different kinds of information.

In the literature review on concepts of nature and environment, Atasoy (2005) investigated elementary school students' attitudes towards the environment and their knowledge about the environment. Berberoğlu (2015) observed the effect of ecopedagogic-based extramural education on environmental awareness. Deniş and Akar (2015) and Kahyaoğlu (2015) investigated using nature related perceptions through metaphors on middle school and elementary school students, respectively. Erdoğan (2011) examined the impact of nature education on the sensory tendencies of elementary school students, towards the environment and responsible behavior, using an ecology-based program. Güler (2009) observed the nature related opinions of teachers, who participated in ecology-based environmental training. Furthermore, the study by Kahyaoğlu and Yetişir (2015) observed the perceptions of teachers, regarding nature and students growing apart from nature. Kıyıcı, Yiğit, and Darçin (2014) explored the impact of nature education on the rate of change in prospective teachers' environmental literacy. Köşker (2013) and Kutru and Soran (2012) investigated the nature related perceptions 
of prospective teachers and university students, respectively. Özdemir (2010) observed the effect of environmental education of primary school students, based on their experiences of nature, perception, and behavior related to nature. Altunoğlu and Atav (2009) explored the environmental risk perceptions of middle school students, while Demirbaş and Pektaş (2009) examined the level of primary school students' realization of the basic concepts related to environmental problems.

When they reviewed the literature on the cognitive structures related to this field on students in Turkey, Bahar and Özatl (2003) examined high school students' cognitive structures on the essential components of living things. In Ercan, Taşdere, and Ercan's (2010) study, they examined 7th grade elementary school students' cognitive structures related to the solar system and space. In Kurt's (2013) study with prospective biology teachers, he explored their cognitive structures regarding enzymes. In another study by Kurt and Ekici (2013), they examined the cognitive structures of prospective biology teachers related to virus concepts. Polat (2013) investigated the cognitive structures of middle school students on the concept of environment. In their study, Dinçol-Özgür and Yılmaz (2013) analyzed the cognitive structures of prospective chemistry teachers' on their environment related approaches. In a study with middle school students, ranging from 12-14 years old, Özata-Yücel and Özkan (2015) observed the students' cognitive structures related to ecological concepts. Önel and Yüce (2016) examined prospective science teachers' cognitive structures relating to evolution. Atabek-Yiğit, Y1lmaz, and Çetin (2016) analyzed the cognitive structures of prospective class teachers related to certain basic science concepts. Kaya and Akış (2015) explored the cognitive structures of geography students' relating to the concept of air. However, there were insufficient studies on the cognitive structures of middle school students related to concepts of nature and environment. Determining the cognitive structures of middle school students' concepts regarding nature and environment is considered to be important, in order to identify both the perception of these concepts and in nature and environmental education.

\section{Purpose of the Study}

The purpose of this study is to determine the cognitive structures of middle school students in relation to the concepts of nature and environment. Additionally, it is aimed to tangibly determine the students' perceptions regarding nature and environment.

\section{Methods}

\section{Research Pattern}

In this study, a type of qualitative research pattern and phenomenological pattern was used. In the world we live in, facts can be encountered in various forms, such as perceptions, tendencies, concepts, and situations. Phenomenology is a research pattern that helps us understand facts that although are not unknown to us, at the same time are not entirely comprehended. With this approach, the researcher (Yildirim \& Simsek, 2005) was interested in the personal experiences of the participants and explores the perceptions and meanings that they attributed to events.

\section{Study Group}

The study group consisted of 137 middle school students who received education in the 2016-2017 academic year and from schools located in the central part of the Siirt Province in Turkey that are part of the directorate of national education. The study group was formed using one of the random sampling methods-simple random sampling. In this sampling method, the units in the universe have an equal and 
independent chance of being selected as samples. In other words, individuals have equal chance of being selected and the selection of one individual does not impact the selection of other units. Simple random sampling is an effective and the best way of selecting a representative sample (Büyüköztürk, Çakmak, Akgün, Karadeniz, \& Demirel, 2014)

\section{Data Collection Tool}

In this study, the Word Association Test was used as the data collection tool. The Word Association Test is one of the oldest and most widely used methods to determine the students' cognitive structures and the inter-connection among the concepts. In other words, it is used to solve the information network and whether or not the relationship among the concepts in the long-term memory is adequate (Ozatli \& Bahar, 2010). To establish this test, two key constituting concepts - nature and environment were selected. In the first section of the data collection, middle school students' personal information, such as class and gender, were collected. And in the second section, key concepts - nature and environment, with each corresponding to one page were organized as shown in the example below.

Nature:

Environment:

\section{Related Sentence}

Before beginning the intervention, the middle school students were given explanations regarding the Word Association Test. Students were allowed two minutes for each concept, making a total of four minutes. In this time frame, the middle school students were asked to write down response words related to the key concepts. Each key concept is aligned, one under the other, down the page. This is to prevent the risk of writing the response words in a sequence. At the end of the response words corresponding to each key concept, "the related sentence" segment is given. In this section, the middle school students were asked to write the sentence that came to mind, related to the key concept. Since the related sentence would be more complex. At a higher level, whether the sentence is scientific or not and whether it contains different types of concept errors or not, a single response word - evaluation of conditions is effective in the analysis (Ercan, Taşdere, \& Ercan, 2010).

\section{Data Analysis}

In order to analyze the results of the Word Association Test, the responses given to the key concepts were evaluated in detail. A detailed frequency table was prepared showing the repeat frequency of each word or concept corresponding to each key concept. A concept network was established using the frequency table. For the establishment of a concept network, the cut-off point method developed by Bahar, Johnstone, and Sutcliffe (1999) was used. This method suggests that certain frequency points below the most frequent response word given for any key concepts in the frequency table are identified as the cut-off point. This frequency constitutes the first part of the concept network for concepts above. Subsequently, the cut-off point is brought down with specified intervals and this operation is continued until all key words appear in the concept network. In the study, the data are interpreted by scrutinizing the attributed relationships between concepts and newly produced words with the help of the concept network formed using the cut-off point method. By using this method in the data analysis, cut-off points, such as $50-50^{+}, 40-49,30-39,20-29$, and 9-19 were established to form concepts networks. 


\section{Results}

In this section, data obtained from the Word Association Test taken by participating middle school students is presented. The total number of words produced by middle school students and the number of words produced for each key concept are given in Table 1.

Table 1

The Total Number of Words, Including Key Concepts and Responses

\begin{tabular}{lc}
\hline Key words & Number of words \\
\hline Nature & 669 \\
Environment & 653 \\
Total & 1,322 \\
\hline
\end{tabular}

As shown in Table 1, the middle school students produced 1,322 words related to nature and environment. The students produced 669 words related to nature concept and 653 words related to environment concept. The concept network formed by words produced by students related to the two key words - nature and environment, with a cut-off point corresponding to a frequency of 50 or more are represented in Figure 1.

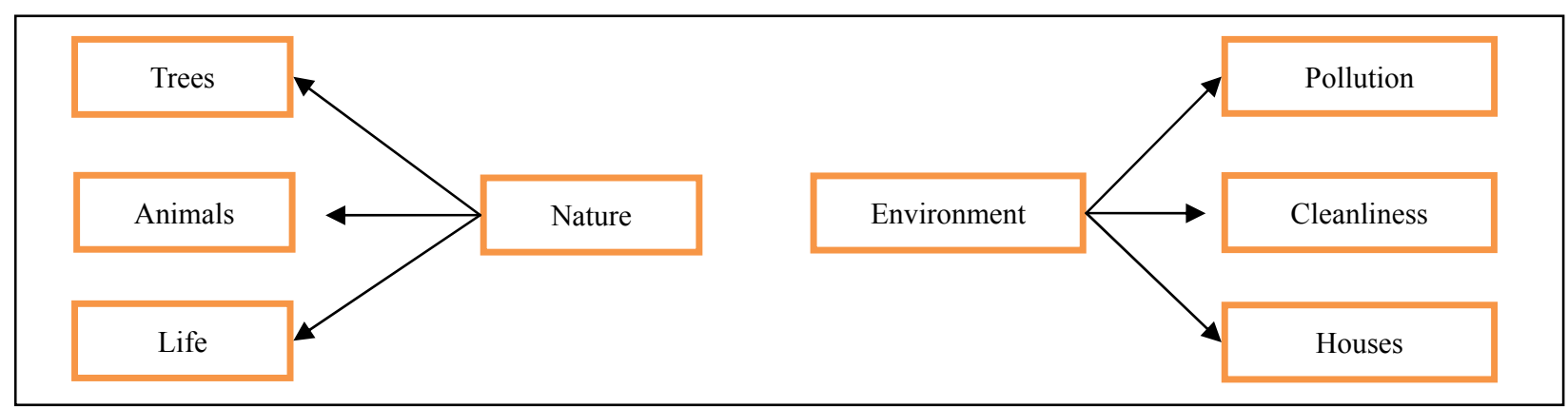

Figure 1. The concept network established with $50-50^{+}$cut-off points.

As shown in Figure 1, it was identified that for the $50-50^{+}$cut-off points, the first words in the students' cognitive structures related to nature concept were "trees," "animals," and "life." In addition, related to the key concept - environment, the first ones were "pollution," "cleanliness," and "houses." However, it was also found that for these cut-off points, the middle school students failed to make a connection with key concepts - nature and environment in their cognitive structures. The concept network formed with words produced by middle school students' in the 40-49 cut-off points is given in Figure 2.
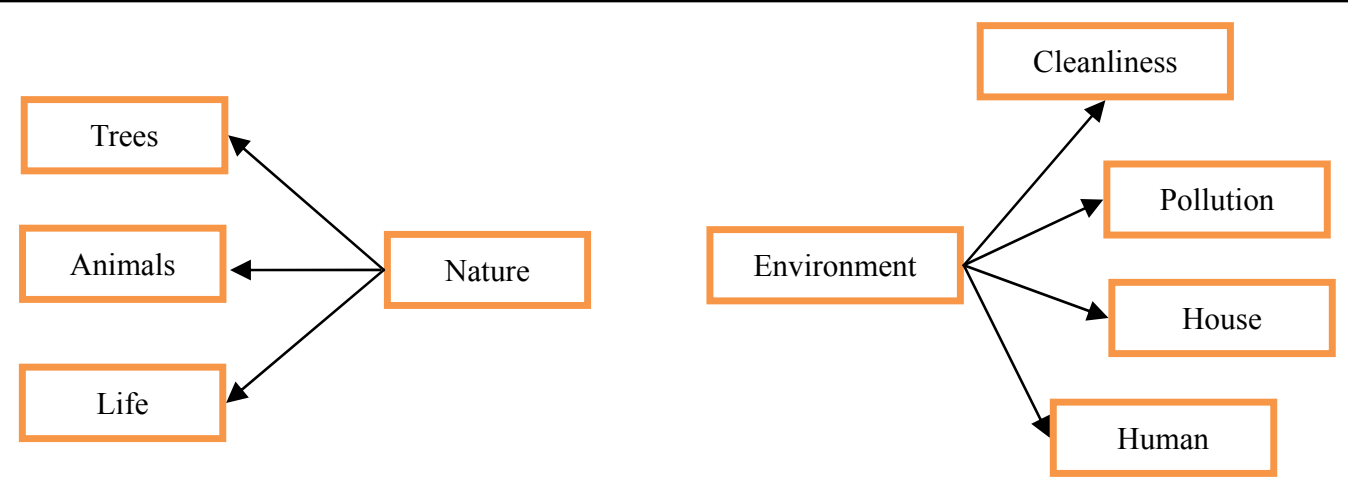

Figure 2. The concept network established with 40-49 cut-off points. 
As shown in Figure 2, when compared to the previous cut-off points, it was identified that for these cut-off points students were found not to produce any words related to the nature key concept, whereas they were found to produce the word "human" in relation to the environment key concept. With this cut-off point, it was found that the middle school students failed to associate concepts of nature and environment and these concepts were disconnected and detached in their cognitive structures. The concept network established with 30-39 cut-off points for the words produced is given in Figure 3.

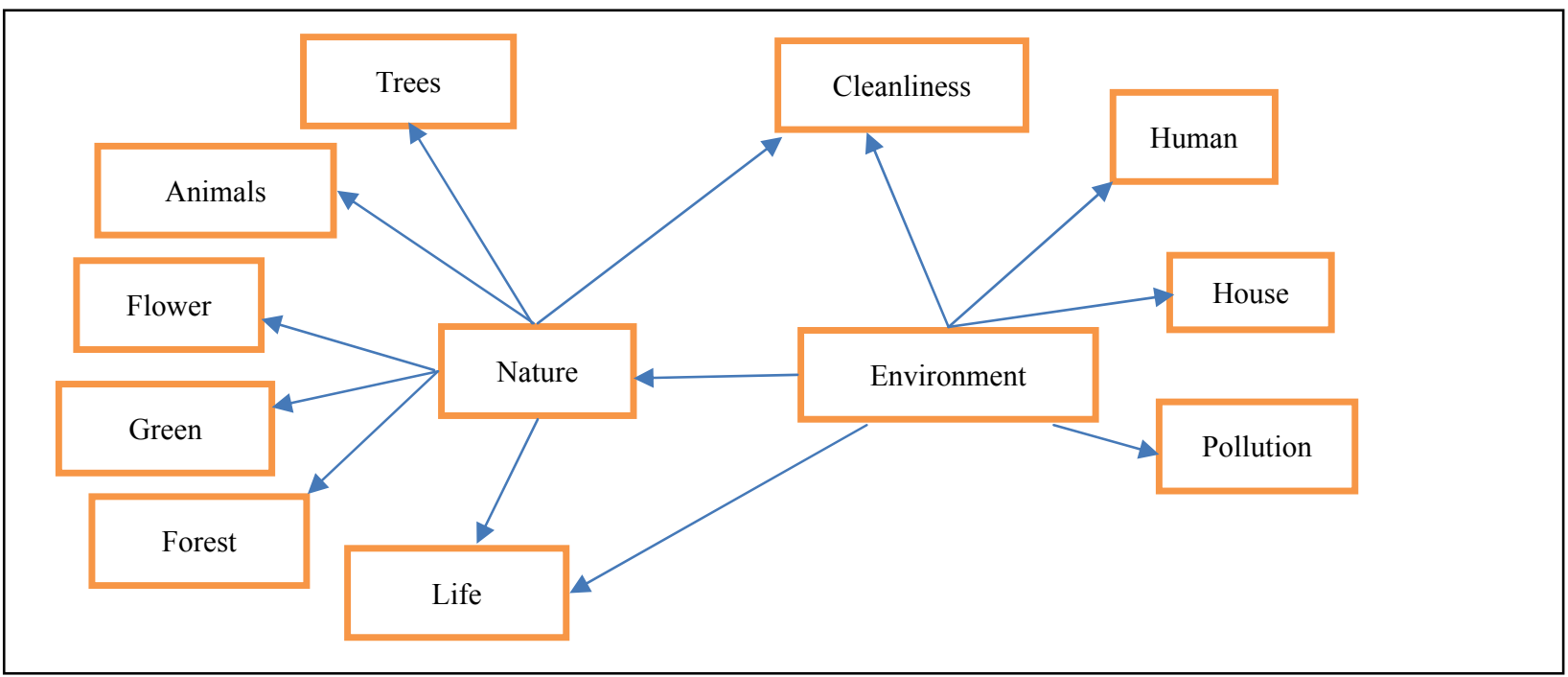

Figure 3. The concept network established with 30-39 cut-off points.

As shown in Figure 3, it was identified that for these cut-off points, students associated the nature key concept with "green," "forest," and "flower" words and they associated the environment key concept with the "nature" word in addition to the previous words. Additionally, for these cut-off points, the students participating in the study were also found to associate the words "cleanliness" and "life" with both nature and environment key concepts. The concept network established with 20-29 cut-off points is given in Figure 4.

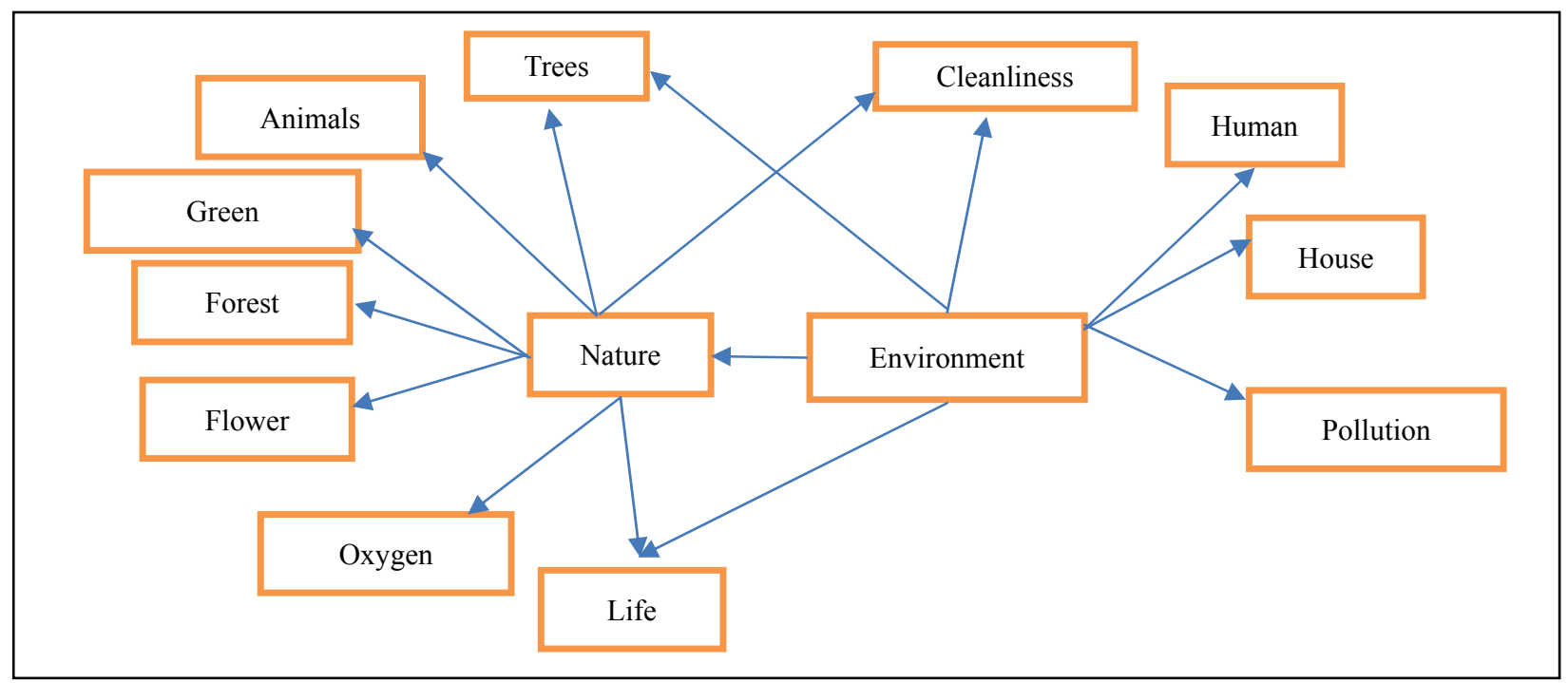

Figure 4. The concept network established with 20-29 cut-off points. 
In the cut-off points in Figure 4, the nature and environment key concepts were found to have a relationship and they were found to appear in the cognitive structure. When the research findings were analyzed, compared with the previous cut-off points, it was found that for these cut-off points the students were found to associate the nature concept with the word "oxygen" and the environment concept with word "tree." The concept network established with 9-19 cut-off points for the words produced is given in Figure 5.

As shown in Figure 5, for these cut-off points, there was an increase in the words produced that were related to nature and environment concepts. In relation to the nature key concept, it was determined that the words not previously produced, such as "tranquility," "happiness," "beauty," "living thing," and "plant." In relation to the environment concept, it was found that the words "air," "car," and "milieu" were produced. Additionally, the words "human," "green," "health," and "animals" were found to be associated with both nature and environment key concepts.

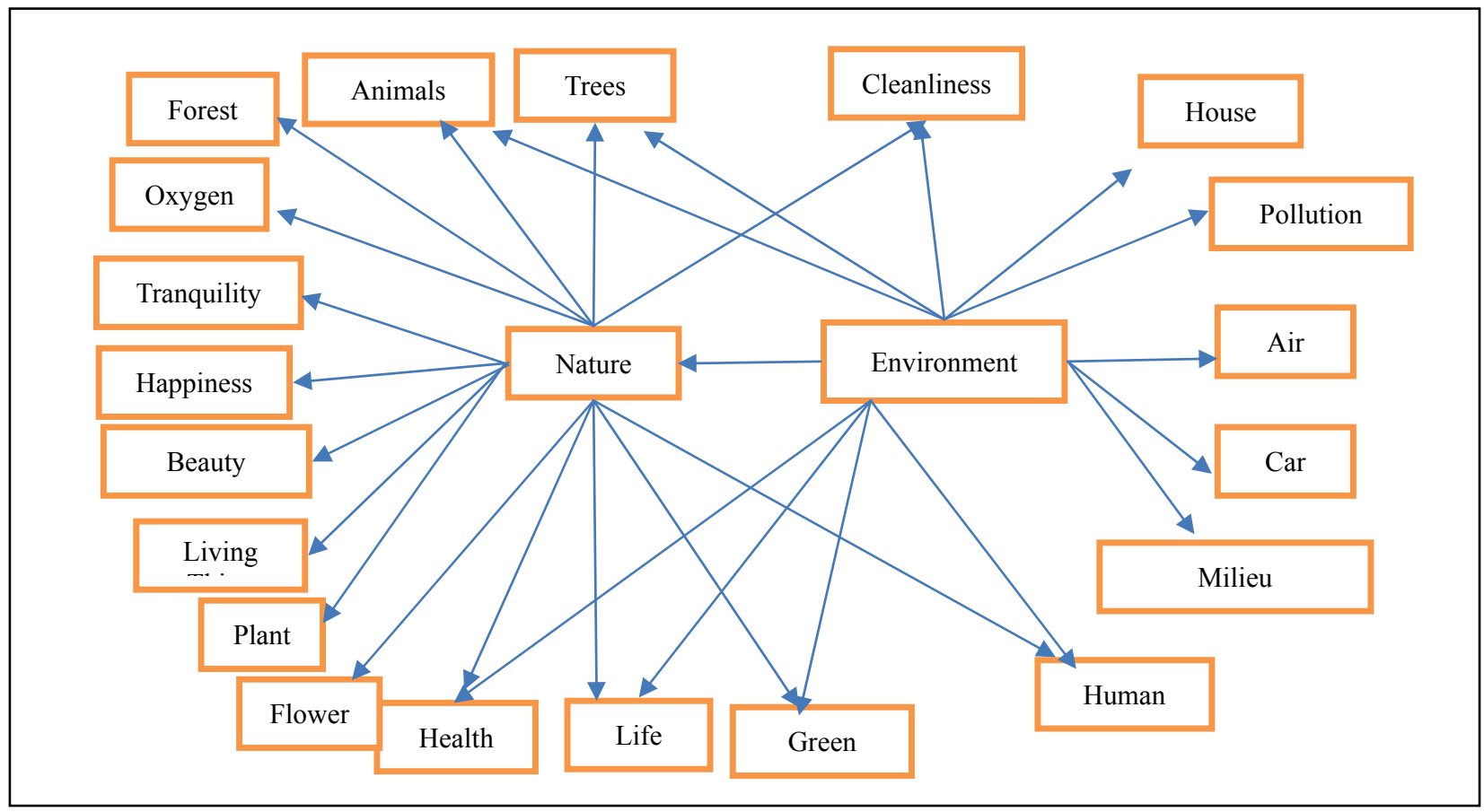

Figure 5. The concept network established with 9-19 cut-off points.

Table 2

Frequency Table of Sentences Formed by Students in Relation to Nature and Environment Concepts

\begin{tabular}{llll}
\hline Key concepts & $\begin{array}{l}\text { Number of sentences containing } \\
\text { scientific information }\end{array}$ & $\begin{array}{l}\text { Number of sentences containing non-scientific } \\
\text { information or superficial information }\end{array}$ & $\begin{array}{l}\text { Number of sentences } \\
\text { containing concept errors }\end{array}$ \\
\hline Nature & 3 & 130 & 4 \\
Environment & 2 & 131 & 4 \\
\hline
\end{tabular}

The findings from the analysis of sentences associated with nature and environment key concepts formed by middle school students are given. According to these findings, if the sentences formed by students relating to nature and environment key concepts are linked to the scientific definitions, they would be categorized as sentences containing "scientific information." Likewise, if the sentences formed by students were those expressed in daily life and not necessarily scientific but used correctly in terms of content, then those would be 
categorized as "non-scientific" or "superficial information." However, if the sentences formed by students were scientifically wrong or carried different meanings, they were categorized as "concept errors." For example, the findings related to this are presented in Table 2 .

As shown in Table 2, it was found that there were three scientific, 130 non-scientific, and four concept error sentences formed by the middle school students related to the nature key concept. When the sentences related to the environment key concept were analyzed, there were two scientific, 131 non-scientific, and four concept error sentences. Accordingly, the majority of the students' cognitive structures constructed sentences containing both non-scientific and superficial information. For example:

1. Nature is part of the universe allowing shelter for all living things. (scientific information)

2. Nature is the future of human beings and the habitat for all living things. (scientific information)

3. Our habitat forms the environment. (scientific information)

4. Human beings are a part of nature. (superficial information)

5. Nature has a unique beauty. (superficial information)

6. Life is a clean environment. (superficial information)

7. Environment must be protected. (superficial information)

8. Nature is the habitat of human beings. (concept error)

9. Environment is the country where human beings can walk without obstacles. (concept error)

\section{Discussion}

In this study, the Word Association Test was used to determine the cognitive structure of middle school students regarding concepts of nature and environment and the students were asked to think of words related to these concepts. The number of words produced and the relationship of words were evaluated to determine the cognitive structure of middle school students. The Word Association Test is one of the alternative methods that demonstrate the cognitive structure of students and the connection among the concepts and could be used to determine whether the connections among these concepts in the long-term memory are adequate or meaningful (Bahar, Johnstone, \& Sutcliffe, 1999). In this study, when the number of words produced relating to concepts of nature and environment are analyzed, it was found that the middle school students produced a total of 1,322 words. The number of words produced relating to the concept of nature was 669 and 653 words for the concept of environment. Based on this, it can be inferred that they have an almost equal number of concepts in their minds related to concepts of nature and environment. The ability to comprehend a concept depends on the associated words. Bahar, Nartgün, Durmuş, and Bıçak (2006) suggested that the number of words associated with a concept could determine whether or not the concept was understood and that concepts not associated with any words would not have any meaning for the students. This also applies to the type, number, and content of words associated with concepts of nature and environment. In the Word Association Test related to the nature and environment key concepts, the number of words given to each key concept was not sufficient. At the same time, the number of common words of both key concepts and the sequence of the production of words were also important. For this reason, concept networks were produced to evaluate the relational meaning of words related to nature and environment and relationship between concepts was analyzed. In the concept network formed with 50-50 cut-off points. "Trees," "animals," and "life" words were associated with nature key concepts, whereas "cleanliness," "pollution," and "house" words were associated with key concepts of the environment. According to this finding, it was implied that in the minds of the middle school students, there 
were no associations between concepts of nature and environment. When the $40-49$ cut-off points were analyzed, in the middle school students' cognitive structure, there were no new words related to the nature concept and the only word produced related to environment concept was "human." In this study, for these cut-off points, it was found that the middle school students were not able to mentally associate concepts of nature and environment. Therefore, it can be inferred that these key concepts are not found as an integrated network in the minds of the students. They were not associated and were disconnected in their minds, thus, they were not comprehended as a whole. This can be explained by the middle school curriculum not attaching enough importance to the relationship between nature and environment.

In the study, the first association of nature and environment concepts was found in the concept network for the 30-39 cut-off points. According to this, the nature concept was associated with the word "cleanliness" and the environment concept was associated with the word "life." Therefore, it can be inferred that the relationship between the concepts of nature and environment forms slowly in the students' cognitive structures. In addition, it can be stated from the association formed by the students between both the concepts of nature and environment with the words "life" and "cleanliness," the conservation of nature and environment is perceived as an important precept for humans. When the concept network established for the 20-29 cut-off points were analyzed, it was found that the environment key concept was first associated with the word "tree" after the word "human," thus, it was associated with a living thing other than humans in the cognitive structures of students. Therefore, it can be inferred that the middle school students first associated the environment key concept with humans in their cognitive structure, and then with other living things. This can be explained by the fact that students grew up in a superficial environment (house, flat, or cities) and had limited experience of the natural environment. When the concept network established was analyzed in the 9-19 cut-off points, there was an increase in the number and type of words produced that were associated with both nature and environment. Additionally, it was found that in the cognitive structure of middle school students there were many words associated with both nature and environment. Moreover, it was found that the concept of nature was associated with the words "abundance" (forest, living things, green, and flower) and "health" (tranquility, happiness, beauty, and oxygen), while the concept of environment was associated with the words "place" or "milieu" (milieu, car, air, and house).

\section{Conclusion}

In this study, when the sentences formed by the middle school students related to the concepts of nature and environment were analyzed, it was found that there were many sentences containing superficial and non-scientific information relating to both nature and environment. It was also found that the students formed very few sentences containing scientific information related to both nature and environment. According to Ercan, Taşdere, and Ercan (2010), the fact that students were not able to form a meaningful sentence, or not form a sentence at all, using the key concepts, is a finding that suggests the students were not able to comprehend these concepts in a meaningful way on a conceptual basis. Based on this statement, it can be stated that the middle school students did not have sufficient information on a conceptual basis. In conclusion, this study found that the sentences formed by the majority of middle school students in relation to nature and environment concepts mainly contained non-scientific and superficial information. These are sentences that are used in daily life, while not generally wrong, have no scientific meaning. 


\section{References}

Altunoğlu, B. D., \& Atav, E. (2009). Secondry school students' environmental risk perception. Hacettepe University Journal of Education, 36, 1-11.

Atabek-Yigit, E., Yilmazlar, M., \& Cetin, E. (2016). Investigation of classroom teacher candidates' cognitive structures on some basic science concepts. European Journal of Education Studies, 1(4), 33-57.

Atasoy, E. (2005). Environmental education: A study for elementary school students' environmental attitude and knowledge (Doctorate's thesis, University Social Sciences Institute, Bursa, Turkey).

Bahar, M., Johnstone, A. H., \& Sutcliffe, R. G. (1999). Investigation of students' cognitive structure in elementary genetics through word association tests. Journal of Biological Education, 33(3), 134-141.

Bahar, M., \& Özatl1, N. S. (2003). The research of cognitive structures on the basic components of living things by high school students with the word association test. Journal of Ballkkesir University Institute of Science and Technology, 5(1), 75-85.

Bahar, M., Nartgün, Z., Durmuş, S., \& Bıçak, B. (2006). Traditional alternative measurement and evulation handbook. Ankara: Pegem A publishing.

Berberoğlu, E. O. (2015). The effect of eco-pedagogy-based outdoor environment education on environmental awareness. Journal of the Hasan Ali Yucel Faculty of Education, 12-1(23), 67-81.

Berberoğlu, E. O. (2015). The opinions of the in service teachers to eco-pedagogy-based environmental education depend on holistic perspective. Mersin University Journal of the Faculty of Education, 11(3), 732-751.

Büyüköztürk, Ş., Çakmak, E., Akgün, Ö., Karadeniz, Ş., \& Demirel, F. (2014). Scientific research methods. Ankara: Pegem A. Publishing.

Çepni, S. (2008). Teaching science and technology from theory to practice (7th ed.). Ankara: Pegem A. Publishing.

Demirbaş, M., \& Pektaş, H. M. (2009). Elementary students' levels of realization of basic concepts related with environment problem. Necatibey Faculty of Education Electronic Journal of Science and Mathematics Education, 3(2), 195-211.

Deniş, Ç. H., \& Akar, A. (2015). Metaphors regarding to nature of middle school students. Journal of Kirşehir Education Faculty, 16(2), 101-119.

Dinçol-Özgür, S., \& Yılmaz, A. (2013). The effect of environmental education on the pre-service teachers' affective tendency towards the environment and cognitive structure. Procedia-Social and Behavioral Sciences, 106, 2704-2713.

Ercan, F., Taşdere, A., \& Ercan, N. (2010). Observation of cognitive structure and conceptual change through word association test. Turkish Science Education, 7(2), 136-154.

Erdoğan, M. (2011). The effects of ecology-based summer nature education program on primary school students' environmental knowledge, environmental affect, and responsible environmental behavior. Educational Sciences: Theory \& Practice, 11(4), 2223-2237.

Güler, T. (2009). The effects on an ecology based environmental education on teachers' opinions about environmental education. Education and Science, 34(151), 30-43.

Kahyaoğlu, M. (2015). An investigation of the concept of nature among elementary school students through metaphors analysis. Turkish Studies International Periodical for the Languages, Literature, and History of Turkishor Turkic, 10(11), 831-846.

Kahyaoğlu, M., \& Yetişir, İ. (2015). A phenomenographic study on the concept of nature and alienation of chilren from nature. Education and Science, 40(182), 159-170.

Kaptan, F. (1999). Fenbilgisi öğretimi (Teaching of science). İstanbul: MEB Yayınları.

Kaya, B., \& Akış, A. (2015). Determination of cognitive structure of geography students' on wheather concept through word association test. Turkish Studies International Periodical for the Languages, Literature, and History of Turkish or Turkic, 10(7), 557-574.

Kıyıcı, B. F., Yiğit, E. A., \& Darçın, E. S. (2014). Investigation of pre-service teacher's opinion and environmental literacy level change with nature education. Trakya University Journal of Education, 4(1), 17-27.

Köşker, N. (2013). Elemantary school students' and prospective elemantary school teachers' perceptions of nature and thougts of the their responsibilities towards the nature. Turkish Studies International Periodical for the Languages, Literature, and History of Turkish or Turkic, 8(3), 341-355.

Kurt, H. (2013). Determining biology student teachers' cognitive structure on the concept of enzyme. Gazi University Journal of Gazi Educational Faculty, 33(2), 211-243.

Kurt, H., \& Ekici, G. (2013). What is a virus? Prospective biology teachers' cognitive structure on the concept of virus. International Online Journal of Educational Sciences, 5(3), 736-756. 
Kutru, Z., \& Soran, H. (2012). Indigenous perceptions of university students. Retrieved May 15, 2015, from http://www.kongrenigde.edu.trxufbmek/dosya/bildiri.pdf

Ministry of National Education (MNE). (2005). Retrieved from http://www.meb.gov.tr

Polat, G. (2013). Determination of the cognitive structures of year secondary school students through word association test techniques. Necatibey Faculty of Education Electronic Journal of Science and Mathematics Education, 7(1), 97-120

Önel, A., \& Yüce, Z. (2016). Determining the cognitive structures of science teacher candidates on "evolution" through word association test. Journal of Educational Sciences Research, 6(1), 23-39.

Özata-Yücel, E., \& Özkan, M. (2015). Determination of secondary school students' cognitive structure and misconception in ecological concepts through word association test. Educational Research and Reviews, 10(5), 660-674.

Özatl1, N. S., \& Bahar, M. (2010). Revealing students' cognitive structure regarding excretory system by new technology. Abant Izzet Baysal University Journal of Education, 10(2), 9-26.

Özdemir, O. (2010). The effects of nature based environmental education on environmental perception and behavior of primary school students. Pamukkale University Journal of Education, 27, 125-138.

Senemoğlu, N., (2010). Evolution learning and teaching (17th ed.). Ankara: Pegem A. Yayınları.

Uçak, N. Ö., \& Güzeldere, Ş. O. (2006). The Impact of cognitive structure and processes on information seeking. Turkish librarianship, 20(1), 7-28.

Yücel, E. (2006). Canlılar ve çevre (Living and environment). Retrieved December 10, 2016, from http://www.aof. edu.tr /kitap/I OLTP/2281/unite05.pdf

Yıldırım, A., \& Şimşek, H. (2005). Research methods in social sciences. Ankara: Seçkin Yayıncılık. 